also of the sheaf form, which I have seen in storms directly overhead, the flash being like two brushes discharging in opposite directions, recalling the classical representations of the lightning in the hand of Jupiter.

Yattendon, Newbury, November 8.

\section{An Early Reference to Hydractinia?}

IN Swammerdam's letter to Thevenot on the anatomy of the Hermit Crab, there seems to be a reference to Hydractinia. The passage ("Biblia Nature," Leyden, I737, i. I97) runs thus :"Maximas tamen omnes [conchas] Fuci marini quadam species, punctis vel apicibus minutis assurgens, obtegebat eousque; ut tota nonnullarum figura obscurata \& deformata esset; neque spiralium, quibus gaudent, convolutionum ulla posset conspici."

I venture to suggest that the words in italics fairly (though, of course, not literally) correspond to the "chitinous crust covered with numerous grooved and serrated spines" of Hincks ("Brit. Hydroid Zoophytes," i. 23, 24). The obliteration by Hydractinia of the whorls of shells tenanted by the Hermit Crab is well-known. Specimens showing such obliteration may be seen in the Natural History Museum, South Kensington.

Harringay, $N$.

HENRY SCHERREN.

\section{Rooks and Wainuts.}

MR. REID's remarks on rooks carrying off acorns, suggests my mentioning that they are great depredators of my walnuts. They come early in the morning, attack the walnuts on the trees, and carry them off to an adjoining field, where they punch a hole in the shell and extract the contents.

They build on several groups of elms in Ealing, and on one row of trees close to Christ Church they come regularly at Christmas to see what repairs are required; but one tree, which has an electric wire running through it, they now entirely avoid. George Henslow.

\section{A Substitute for Sulphuretted Hydrogen.}

HaS "Rusticus" (see vol. lii. p. 597) heard of liquefied $\mathrm{H}_{2} \mathrm{~S}$ ? I have tried it, and find it works admirably. Unlike ammonium thio-acetate, it can be obtained from any of the usual chemical dealers; a bottle containing a pound, = I I cubic feet, can be had for a few shillings. It is always on hand when required, and entirely dispenses with the old $\mathrm{H}_{2} \mathrm{~S}$ apparatus and its abominations. A very great desideratum is the purity of the liquefied gas. Chemicus.

\section{A GERMAN IMPERIAL INSTITUTE.}

$\mathrm{T}$ his presidential address to the British Association at Ipswich, reported in NATURE on September 12, Sir Douglas Galton referred to the efforts made by the German Government and Municipalities to advance scientific knowledge and promote research. In his statement that the "Royal Technical High School" at Charlottenburg "casts into shade the facilities for education in the various Polytechnics which we are now establishing in London," he scarcely appreciates the radical distinction between the German and London institutions, which accidentally bear the same name, but which are wholly different in purpose and organisation. But his remarks on the Reichsanstalt of Berlin are so suggestive and so full of interest, that I was eager to have the opportunity of visiting the Institute, and was glad within the last week or so to be able, during a brief stay in Berlin, to make myself better acquainted with its work.

The Institute, as its name implies, is an "Imperial Institute," as distinguished from the Polytechnicum, which is under the Government of the Prussian State. The Polytechnicum, or Technical High School, has been already described in NATURE, and is one of a number of technical universities situated in the several States which compose the German Empire. The Berlin Institute at Charlottenburg is by far the largest and the most completely equipped in Europe, and is already pronounced too small for the ever-increasing number of students, now exceeding
3000. In close proximity to this building in the Marsch Strasse, a turning in the leading avenue through the Thiergarten, the Physical-Technical Imperial Institute is now being erected. When complete it will consist of three detached buildings, in addition to separate residences for the Director and for some members of his staff. Two of these buildings are already finished, but the third is not yet erected, and pending its completion the work of this section of the Institute is carried on in a portion of the basement of the Royal Polytechnic.

The work of the Institute consists of two separate, but in some respects associated, sections. Section I. is devoted to pure scientific research, and Section II. to the testing and standardising of different kinds of measuring instruments. The Research Department is already housed in the main building of the new Institute, which has been planned especially for the purpose ; whilst much of the testing work of the other department is still carried on in the Polytechnic building. The united Institute is under the general direction of Dr. Kohlrausch, and is maintained at an annual cost to the Government of about fI 5,000 .

The Research Department of this interesting Institute is housed in a three-storeyed building, consisting of a basement, a main floor, and an upper storey. The construction is in many respects peculiar. The walls, instead of resting on separate concrete foundations, are built into a concrete flooring two metres deep, which covers the entire area of the building, so that the walls, basement, and flooring are closely bound together. The effect of this is that the building, if it vibrates at all, must vibrate as a whole, and no one part is separated from another. There is consequently no need for the isolated pillars which are found in some of our English labora. tories. But even this arrangement does not appear to be perfect, and although the building is well set back from the road, in which there is some traffic, vibratory movements are not entirely avoided. The principal floor of the building consists of a central room, used mainly for experiments requiring constant temperature, surrounded by a corridor which leads into a number of other laboratories for experiments in electricity, magnetism, light, and heat. There are various interesting arrangements for maintaining the constant temperature of the central room, including the admission of light from the top through a series of separated glass roofs. The experimental work of the first section, or "Abtheilung," is under the direction of three heads of departments, Drs. Thiesen, Jaeger and Lummer, who occupy themselves respectively with investigations in heat, electricity, and light. They are aided by a number of permanent assistants, and by other workers who are admitted into the Institute for the prosecution of some special investigation. The members of the staff are engaged entirely in research, and have no teaching duties. The researches of the staff during the past year comprise numerous investigations connected with the determination of the expansion of bodies under heat; experiments with different kinds of thermometers, and pyrometers; electric and magnetic investigations; and photographic and photometric experiments. Short notices of these researches, giving the results as ascertained, are annually published.

Section $I$. is occupied exclusively with the testing of different measuring instruments. The makers of thermometers, manometers, and pressure gauges of all sorts, send their instruments to the Institute to be tested. Galvanic elements, accumulators, arc lights, ammeters, electric condensors, resistance coils, \&c., are being tested in different parts of the building. No measurements connected with weight or mass are undertaken, and the testing of the strength of materials for builders and engineers is carried on in other buildings in no way connected with the Institute. The number of thermometers alone sent to the

No. I 359 , VOL. 53$]$ 